\title{
PENGARUH PENERAPAN COOPERATIVE LEARNING TIPE CIRC (COOPERATIVE INTEGRATED READING AND COMPOSITION) DALAM KETERAMPILAN MEMBACA (STUDI EKSPERIMEN DI MTS MADINATUNNAJAH CIREBON)
}

\author{
Muna Mutamimah \\ Institut Agama Islam Negeri (IAIN) Syekh Nurjati Cirebon \\ Email: mutamimahmuna20@gmail.com \\ Khasan Aedi \\ Institut Agama Islam Negeri (IAIN) Syekh Nurjati Cirebon \\ Email: khasanaedi@gmail.com \\ Maman Dzul Iman \\ Institut Agama Islam Negeri (IAIN) Syekh Nurjati Cirebon \\ Email: mamandz.iman@gmail.com
}

Diterima tanggal 29-11-2021

Publish tanggal 16-12-2021

\begin{abstract}
Abstrak
Tujuan dari penelitian ini adalah untuk mengetahui kemampuan keterampilan membaca teks bahasa Arab siswa sebelum dan setelah penerapan Cooperative Learning tipe CIRC (Cooperative Integrated Reading and Composition) dan mengetahui pengaruh penerapan Cooperative Learning tipe CIRC (Cooperative Integrated Reading and Composition) siswa kelas VIII MTs Madinatunnajah Kota Cirebon. Penelitian ini menggunakan metode penelitian kuantitatif eksperimen dengan desain one-group pretest-posttest. Metode pengumpulan data yang digunakan dalam penelitian ini melalui observasi, soal tes, dan wawancara. Disamping itu, analisis data dalam penelitian ini menggunakan penghitungan N-Gain, uji normalitas dan uji hipotesis. Sampel yang diambil dalam penelitian ini adalah kelas 2 MTs Madinatunnajah Cirebon tahun ajaran 2020/2021 sebanyak 30 Siswa. Dari hasil penelitian kemampuan membaca siswa melalui soal tes, rata-rata pre-test 59,70 dan rata-rata post-test 76,30. Hasil perhitungan uji-t sig (2-tailed) sebesar 0,000 >0,005, menunjukkan adanya pengaruh penerapan model pembelajaran Cooperative Learning tipe Cooperative Integrated Reading and Composition (CIRC) terhadap kemampuan membaca teks bahasa Arab. Dapat diketahui juga besar pengaruhnya melalui rumus effect size cohen's yaitu sebesar 1,77 dengan kategori kuat. Hal ini membuktikan adanya pengaruh yang signifikan dari model pembelajaran Cooperative Learning tipe Cooperative Integrated Reading and Composition (CIRC) terhadap kemampuan membaca teks bahasa Arab.
\end{abstract}

Kata Kunci: Pembelajaran Koperatif, Keterampilan Membaca

\begin{abstract}
Abstrac
The purpose of this research is to find out students' reading skill in Arabic texts before and after the implementation of cooperative learning, CIRC (Cooperative Integrated Reading and Composition) type and to find out the effect of Cooperative Learning and the type is CIRC (Cooperative Integrated Reading and Composition) of students' reading skill in MTs Madinatunnajah Cirebon. This study used quantitative research as the method, specifically using experimental one-group pretest-posttest. Techniques of collecting data of this
\end{abstract}


research were observation, question making and interview. Besides, the method to analyze the data of this research were statistical normality and hypothesis testing. The sampel were 2nd grade students of MTs Madinatunnajah Cirebon as many as 30 students. The findings from the analysis of students' reading skill in question making test which showed in the average of pre-test is 59.70 and post-test 76.30. The result of $t$ - test sig (2-tailed) is $0,000>0,005$, so it shows that there is an effect of implementation cooperative learning, Cooperative Integrated Reading and Composition (CIRC) type as the learning model to students' reading skill in Arabic texrs. There is also the effect on Cohen's formulation of 1.77 and it is in strong categories. This tertifies prove that there is a significant effect of Cooperative learning, CIRC type to students' reading skill in Arabic texts.

Keywords: Cooperative Learning, Reading Skills

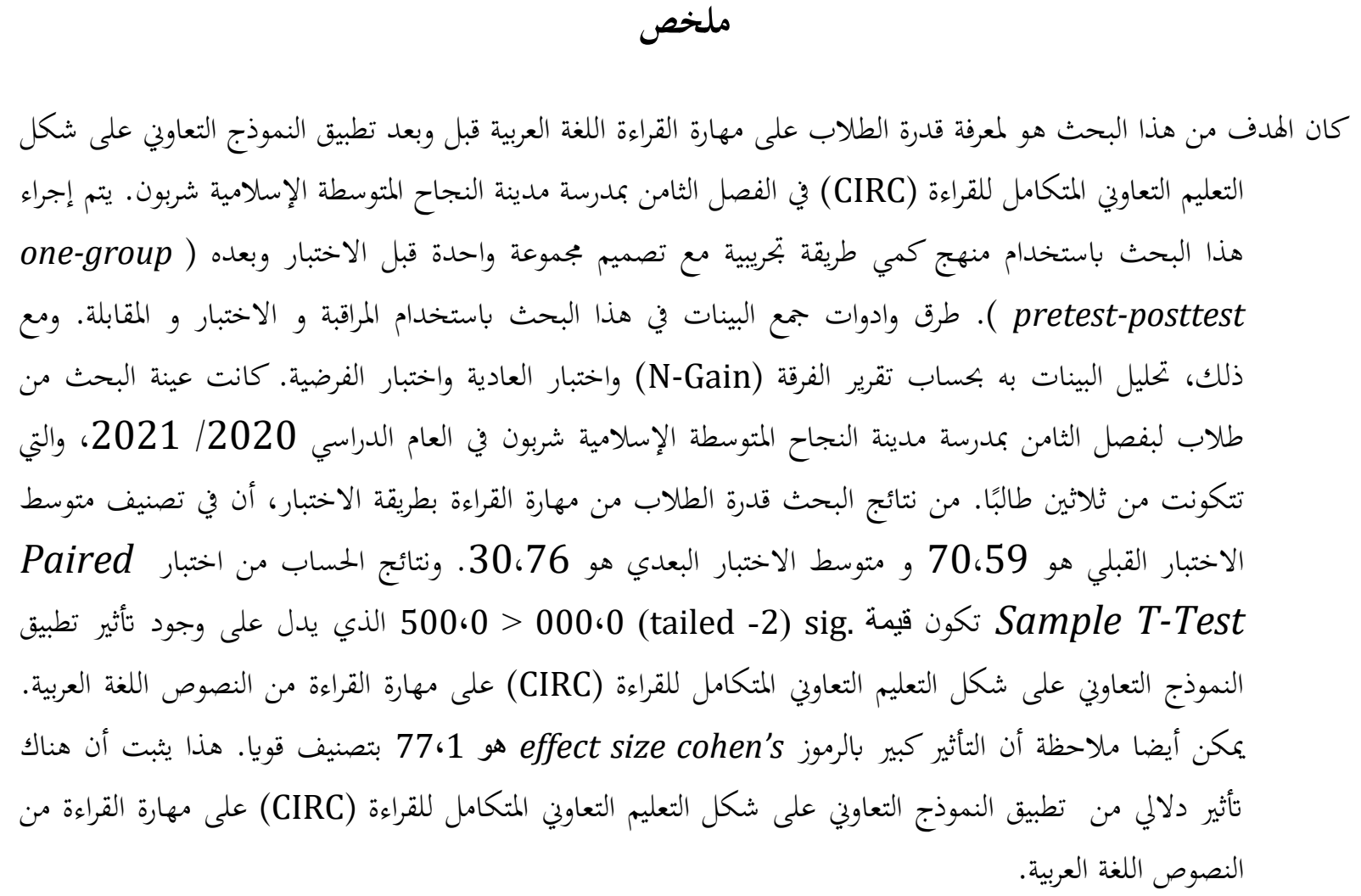

الكلمات المفتاحية: نموذج التعاوبي، مهارة القراءة

\section{Pendahuluan}

Dalam pembelajaran bahasa memiliki 4 keterampilan utama, diantaranya adalah menyimak, berbicara, membaca, dan menulis. Dalam keempat aspek tersebut, selalu berkaitan pada setiap tema pembelajaran dan terdapat bahasan yang meluas. Itulah mengapa pembelajaran bahasa dapat dikatakan rumit. setiap keterampilan itu erat pula dengan proses-proses berpikir yang mendasari bahasa. Bahasa seseorang menceminkan pikirannya. Semakin terampil seseorang berbahasa, semakin cerah dan jelas pula jalan pikirannya. Keterampilan hanya dapat diperoleh dan dikuasai dengan 
jalan praktek dan banyak latihan. Melatih keterampilan berbahasa berarti pula melatih keterampilan berpikir (Farboy, $2008: 416$ ).

Kemampuan membaca merupakan satu diantara keterampilan berbahasa yang sangat penting diajarkan kepada siswa. Kemampuan ini selalu ada dalam setiap tema pembelajaran. Kemampuan membaca menjadi dasar yang utama bagi pengajaran bahasa serta pengajaran mata pelajaran yang lain. Bagi siswa, membaca tidak hanya berperan dalam menguasai bidang studi yang dipelajarinya saja. Membaca berperan dalam mengetahui berbagai macam kemajuan ilmu pengetahuan dan teknologi yang terus berkembang. Manfaat membaca antara lain: Dapat membuka cakrawala kehidupan bagi pembaca, dapat menyaksikan dunia lain, dan merubah pembaca memjadi mempesona dan terasa nikmat tutur katanya. Melaui membaca, kemajuan ilmu pengetahuan dan teknologi dapat diketahui dan dipahami sebelum diaplikasikan (Agasasmita, $2019: 1$ ).

Pada dasarnya, hampir semua jenis membaca memerlukan pemahaman, karena kualitas membaca manusia khususnya kalangan pelajar diukur dari kecepatan membaca, pemahaman yang mendalam, pengingatan kembali, dan penerapan informasi yang didapat secara kreatif (Thama, 2014 : 4). Abdurrahman (2003:212) berpendapat bahwa ada empat kemampuan yang ingin dicapai melalui membaca pemahaman, yaitu “(1) Mengenal kata atau kalimat yang ada dalam bacaan atau mengetahui maknanya, (2) Dapat menghubungkan makna konotatif dan makna denotative dari pengalaman yang dimiliki yang ada dalam bacaan, (3) Mengetahui seluruh makna atau persepsinya terhadap makna itu secara kontekstual, dan (4) Membuat pertimbangan nilai isi bacaan yang didasarkan pada pengalaman bacaan" (Oktafiani, 2018: 19).

Namun, tidak semua siswa memiliki kemampuan yang sesuai dengan tingkatan kelasnya maka diperlukan penanganan khusus untuk membantu siswa yang mengalami kesulitan dalam membaca pemahaman. Sikap positif siswa juga harus ditingkatkan, seperti menumbuhkan rasa percaya diri terhadap kemampuanya untuk berpendapat ketika menyimpulkan pemahaman dari apa yang telah dibaca. Upaya guru untuk memperbaiki pembelajaran adalah dengan memperbaiki strategi, model, ataupun metodenya yang diutamakan. Untuk itu, peneliti mencoba menerapkan model Cooperative Learning untuk membantu mengatasinya. 
Dengan tipe belajar kooperatif, siswa didorong untuk aktif belajar melalui kelompok-kelompok kecil. Siswa saling membantu dan merasa bertanggung jawab terhadap keberhasilan temannya bahkan kesuksesan kelompok ditentukan dari keseluruhan anggota kelompok mampu menguasai materi yang dipelajari (Suarni, 2016: 6). Terdapat beberapa tipe dalam model Cooperative Learning. Diantaranya adalah Student Teams Achievment Division (STAD), Jigsaw, Team Game Tournament (TGT), Group Investigation (GI). Namun, pada penelitian ini akan mencoba menerapkan tipe Cooperative Integrated Reading and Composition (CIRC).

Tipe CIRC berkaitan erat dengan keterampilan membaca dan sesuai dengan tujuan dari penerapan metode CIRC yang dikemukakan oleh Slavin yaitu: (1) Meningkatkan peluang siswa untuk membaca dengan keras, kemudian menerima hasil dari kegiatan membaca, (2) Siswa bekerjasama untuk mengetahui bacaan yang dapat diperluas, dan (3) Untuk menyusun, menerapkan dan mengevaluasi pembelajaran menulis dan seni berbahasa (Nengsih dkk, 2008: 334). Fokus utama kegiatan CIRC adalah membuat penggunaan waktu menjadi lebih efektif. Siswa dikondisikan dalam tim-tim kooperatif yang kemudian dikoordinasikan dengan pengajaran kelompok membaca, kosa kata, pembacaan pesan dan ejaan. Pembelajaran Koperatif tipe CIRC dari segi bahasa dapat diartikan sebagai suatu model pembelajaran yang mengintegrasikan suatu bacaan secara menyeluruh kemudian mengkomposisikannya menjadi bagian-bagian yang penting.

MTs Madinnatunnajah Kota Cirebon merupakan bagian sekolah swasta dari yayasan Pondok Pesantren Madinatunnajah, yang terletak di Jl. Cirebon Permai 3, Kecamatan Harjamukti, Kota Cirebon, dan berdiri pada tahun 1989 M. Jenjang pendidikannya mencakup TK, MI, MTs dan MA. Konsep pendidikan yang diusung oleh pesantren ini adalah modern. Yang mana pendidikan sudah berada di dalam kelas dengan satu kurikulum terpadu yang dikenal dengan nama TMI. Kurikulum seperti model KMI Gontor dan mengutamakan pembelajaran bahasa asing, terutama bahasa Arab.

Idealnya, siswa dapat mahir dalam pembelajaran bahasa Arab terutama keterampilan pemahaman membaca teks bahasa Arab. Namun, berdasarkan hasil observasi langsung dengan mengajar disana, yang difokuskan pada sekolah MTs Madinatunnajah, terdapat beberapa siswa yang masih kesulitan untuk menerjemahkan sesuai konteks dan menemukan ide pokok dalam teks bacaan, terutama siswa kelas 
delapan. Padahal, siswa diwajibkan storan hafalan mufrodat setiap hari sebelum pembelajaran dimulai. Dan berdasarkan Kompetensi Dasar yang diterapkan, siswa kelas delapan dituntut untuk dapat menganalisis gagasan dari teks sederhana.

Proses pembaharuan model dan metode pembelajaran harus dilaksanakan untuk menciptakan kegiatan belajar yang aktif dan kreatif, melibatkan siswa dan menciptakan suasana belajar yang baru dalam setiap kegiatan pembelajaran. Untuk meminimalisir permasalahan dan membantu mencapai tujuan pembelajaran, peneliti tertarik untuk melaksanakan penelitian dengan model Cooperative Learning tipe CIRC. Penelitian ini lebih ditekankan pada penelitian pada penilaian untuk mengukur pembelajaran bahasa pada keterampilan membaca. Indikasi dari keterampilan membaca adalah agar siswa dapat berfikir kritis ketika mendapatkan informasi yang diterima melalui teks bacaan dan bukan hanya sekedar melafalkan bunyi dari symbol dan tulisan saja.

Terkait dengan pemaparan diatas, maka peneliti akan melakukan penelitian mengenai "Pengaruh Penerapan Model Cooperative Learning Tipe CIRC (Cooperative Integrated Reading and Compossition) dalam Keterampilan Membaca (Studi Eksperimen di MTs Madinatunnajah Kota Cirebon)".

\section{Metode Penelitian}

Penelitian ini dilakukan menggunakan pendekatan kuantitatif, yaitu penelitian yang lebih menekankan pada pengumpulan data kuantitif (data yang berupa angka) dan menggunakan analisis statistik sebagai dasar pemaparan data, analisis data dan pengajuan hipotesis serta pengambilan kesimpulan (Sugiyono, 2013: 115). Metode yang digunakan adalah eksperimen dengan desain one group pretest-posttest. Pada desain ini terdapat pre-test (sebelum diterapkan perlakuan) yang dilaksanakan pada tanggal 25 Mei 2021. Sedangkan post-test (setelah ditepakan perlakuan) yang dilaksanakan pada tanggal 5 Juni 2021. Dengan demikian, hasil perlakuan dapat diketahui lebih akurat, karena dapat membandingkan dengan keadaan sebelum dan setelah diberi perlakuan atau diterapkannya model CIRC.

Dalam metode penelitian kata populasi amat popular, digunakan untuk menyebutkan serumpun atau sekelompok objek yang menjadi sasaran penelitian. Oleh karenanya, populasi penelitian merupakan keseluruhan (universum) dari objek 
penelitian yang didapat berupa manusia, hewan, tumbuh-tumbuhan, udara, gejala, nilai, peristiwa, sikap hidup, dan sebagainya, sehingga objek-objek ini dapat menjadi sumber data penelitian. (Bungin, 2006: 109) Populasi dari penelitian ini adalah seluruh siswa MTs Madinatunnajah Kota Cirebon 2020/2021, yaitu kelas VII, VIII, IX A dan IX B.

Sampel adalah bagian dari jumlah karakteristik yang dimiliki oleh populasi tersebut. Dalam penelitian sosial, dikenal hukum kemungkinan - hukum probabilitas yaitu kesimpulan yang ditarik dari populasi dapat digeneralisasikan kepada seluruh populasi. Kesimpulan ini dapat dilakukan karena pengambilan sampel dimaksud adalah untuk mewakili seluruh populasi. Dari ide hukum kemungkinan ini, maka kemudian banyak penelitian menggunakan sampel. (Bungin, 2006: 111) Sampel dalam penelitian ini adalah siswa kelas VIII MTs Madinatunnajah Kota Cirebon 2020/2021 yang terdiri dari 30 orang. Sedangkan, teknik pengambilan sampel yang digunakan adalah purposive sampling, yaitu teknik pengambilan sampel yang memiliki pertimbangan tertentu.

Metode pengumpulan data dalam penelitian ini yaitu dengan observasi, tes, dan wawancara. Proses observasi ini membantu peneliti untuk meneliti secara langsung dan dapat mengamati situasi yang ada di lapangan, guna menunjang terhadap tujuan penelitian. Dengan observasi, penelitian diberikan kemudahan untuk memperoleh data dan dapat digunakan sebagai data pelengkap dari tes yang diajukan. Tes ini berupa pretest dan posttest, yang bertujuan untuk membandingkan keterampilan membaca antara sebelum dan setelah diterapkannya model CIRC. Adapun tes yang digunakan adalah tes tulis yang terdiri dari 20 soal yang telah divalidasi. Wawancara juga digunakan sebagai pelengkap data untuk mengetahui perkembangan pembelajaran keterampilan membaca setelah diterapkannya model CIRC, yang dilakukan dengan guru bahasa Arab dan siswa kelas delapan.

\section{Pembahasan \\ Model Cooperative Learning}

Model Cooperative Learning adalah suatu model pembelajaran dimana siswa belajar dan bekerja dalam kelompok-kelompok kreatif secara kolaboratif yang

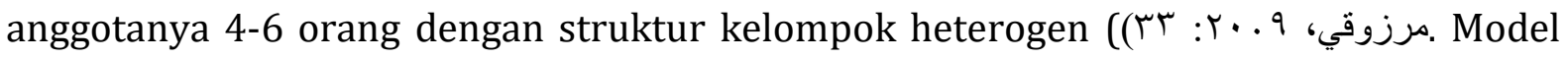
ini juga mendorong siswa untuk mengeluarkan serta mengungkapkan idenya secara 
verbal dan membandingkan dengan ide temannya, serta dapat membantu siswa untuk saling menghormati dan menerima pendapat antar sesama.

Adapun karakteristik dari Cooperative Learning (Pembelajaran Kooperatif) adalah sebagai berikut (Padmadewi, 2017: 33).

a. Saling bekerjasama dengan kelompok heterogen

b. Berinteraksi langsung (face to face interaction)

c. Saling tergantung satu sama lain secara positif (positive interdependence)

d. Setiap anggota kelompok memiliki kontribus yang sama (Individual accountability)

e. Memiliki tujuan yang sama (Working toward achieving the same goal).

Melalui pembelajaran koperatif, peserta didik akan memiliki sikap toleransi terhadap keberagaman, memiliki keterampilan sosial, sikap demokrasi, dan meningkatkan kemampuan berpikir tingkat tinggi.

\section{Model Pembelajaran CIRC}

Pembelajaran kooperatif tipe CIRC merupakan salah satu pembelajaran yang lebih menekankan kepada peserta didik untuk menggunakan metode belajar kelompok. Model pembelajaran ini juga diterapkan dalam proses belajar mengajar dengan harapanmelalui model pembelajaran ini peserta didik lebih termotivasi untuk bereksplorasi dan berinteraksi mengenai materi pelajaran yang telah ada, berdiskusi, saling membantu dan berargumentasi serta mengemukakan idenya (Delviani, 2016: 91). Tujuan utama CIRC adalah menggunakan tim-tim koperatif untuk membantu para siswa mempelajari kemampuan memahami bacaan yang dapat diaplikasikan secara luas (Slavin, 2010: 203).

\section{Keterampilan Membaca}

Membaca merupakan proses berfikir yang meliputi penafsiran simbol-simbol yang diterima pembaca dengan metode yang telah ditentukan (119: عاطى، 1997). Keterampilan membaca merupakan aspek keterampilan berbahasa yang esensial karena keterampilan membaca merupakan dasar untuk menguasai bahasa. Kegiatan membaca pada dasarnya menuntut siswa untuk mampu memahami apa yang dibacanya, memperoleh informasi yang dibaca baik lisan maupun tertulis. 
Pada dasarnya, hampir semua jenis membaca memerlukan pemahaman karena kualitas membaca manusia khususnya kalangan pelajar diukur dari kecepatan membaca, pemahaman yang mendalam, pengingatan kembali dan penerapan informasi yang didapat secara kreatif. Dari sekolah menengah pertama (SMP) siswa mulai banyak diberikan teks atau wacana dalam pembelajaran bahasa Indonesia dengan mengukur kemampuan membaca dari tingkatan SMP dapat membuat untuk kedepannya terbiasa dalam memahami suatu teks bacaan dengan baik (Thama, 2014: 4).

Dalam penilaian kegiatan membaca dapat dilakukan dengan cara penilaian memberikan tes, merespon jawaban menjadi tagihan kinerja berbahasa aktif, produktif, baik yang disampaikan secara lisan maupun tulisan. Bentuk penilaian pada kegiatan ada dua yaitu penilaian penceritaan kembali cerita yang dibaca secara lisan dan penilaian penulisan kembali cerita yang dibaca.

Penilaian penceritaan kembali secara lisan ini bersifat pada aktivitas peserta didik menjelaskan secara langsung. Sedangkan penilaian penulisan kembali cerita yang dibaca ini bersifat tidak langsung dengan menulis.

\section{Hasil Penelitian}

Tabel 1. Statistik Deskriptif

\begin{tabular}{|c|c|c|c|}
\hline \multirow{2}{*}{ Data Statistik } & \multicolumn{3}{|c|}{ Hasil Tes } \\
\cline { 2 - 4 } & Pretest & Posttest & N-Gain \\
\hline Jumlah Siswa & 30 & 30 & a. \\
\hline Maksimum & 95 & 100 & 1 \\
\hline Minimum & 30 & 55 & 0,35 \\
\hline Mean & 59,7 & 76,3 & 0,41 \\
\hline Median (Me) & 60 & 75 & 0,37 \\
\hline Modus (Mo) & 50 & 75 & 0,50 \\
\hline
\end{tabular}

Berdasarkan tabel 1. Terlihat bahwa hasil tes pada keterampilan membaca materi mengalami peningkatan, terlihat pada nilai posttest yang lebih tinggi daripada nilai pretest. Hal itu ditunjang dengan nilai peningkatan atau $\mathrm{N}$-gain sebesar 0,41 yang termasuk dalam kriteria sedang. 


\section{Uji Normalitas}

Tujuan uji normalitas adalah untuk mengetahui apakah data dalam penelitian ini berdistribusi normal atau tidak. Analisis uji statistik yang digunakan adalah One-Sample Kolmogrov-Smirnov, yang dibantu dengan SPSS 21. Tes dikatakan normal apabila lebih besar dari 0,05, jika lebih kecil dari 0,05 maka dikatakan tidak normal.

Hasil dari uji normalitas dalam penelitian ini dapat dilihat pada table 2 .

\section{Tabel 2. One-Sample Kolmogorov-Smirnov Test}

\begin{tabular}{|ll|r|r|}
\hline & & Pretest & \multicolumn{1}{|c|}{ Postest } \\
\hline $\mathrm{N}$ & & 30 & 30 \\
Normal Parametersa,b & Mean & 59.67 & 76.33 \\
& Std. Deviation & 15.082 & 10.250 \\
& Absolute & .106 & .215 \\
Most Extreme Differences & Positive & .106 & .194 \\
& Negative & -.105 & -.215 \\
Kolmogorov-Smirnov Z & & .580 & 1.177 \\
Asymp. Sig. (2-tailed) & .890 & .125 \\
\hline a. Test distribution is Normal. & & \\
b. Calculated from data. &
\end{tabular}

Dari tabel tersebut, dapat diketahui bahwa data pada hasil pretest adalah 0,890 > 0,05 dan hasil posttest adalah 0,125 $>0,05$. Semua data menunjukkan $>0,05$. Hal ini menunjukkan data berdistribusi normal.

\section{Uji hipotesis}

Uji hipotesis pada penelitian ini adalah melalui paired simple t-test dan Cohen's Effect Size, yang dibantu dengan aplikasi SPSS 21.

a. Uji Paired Samples T-test

Tabel 3. Paired Samples Statistics

\begin{tabular}{|rl|r|r|r|r|}
\hline & \multicolumn{1}{|c|}{ Mean } & N & Std. Deviation & Std. Error Mean \\
\hline \multirow{2}{*}{ Pair 1 } & Pretest & 59.67 & 30 & 15.082 & 2.754 \\
& Postest & 76.33 & 30 & 10.250 & 1.871 \\
\hline
\end{tabular}

Tabel 4. Paired Samples Correlations

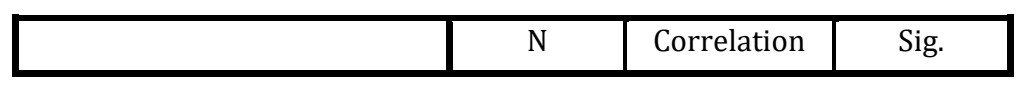




\begin{tabular}{|ll|r|r|r|}
\hline Pair 1 & Pretest \& Postest & 30 & .789 & .000 \\
\hline
\end{tabular}

Tabel 5. Paired Samples Test

\begin{tabular}{|c|c|c|c|c|c|c|c|c|}
\hline & \multicolumn{5}{|c|}{ Paired Differences } & \multirow[t]{3}{*}{$\mathrm{T}$} & \multirow[t]{3}{*}{ Df } & \multirow{3}{*}{$\begin{array}{l}\text { Sig. (2- } \\
\text { tailed) }\end{array}$} \\
\hline & \multirow[t]{2}{*}{ Mean } & \multirow[t]{2}{*}{$\begin{array}{c}\text { Std. } \\
\text { Deviatio } \\
n\end{array}$} & \multirow[t]{2}{*}{$\begin{array}{l}\text { Std. } \\
\text { Error } \\
\text { Mean }\end{array}$} & \multicolumn{2}{|c|}{$\begin{array}{l}\text { 95\% Confidence } \\
\text { Interval of the } \\
\text { Difference }\end{array}$} & & & \\
\hline & & & & Lower & Upper & & & \\
\hline $\begin{array}{ll}\text { Pair } & \text { Pretest - } \\
1 & \text { Postest }\end{array}$ & $\begin{array}{r}- \\
16.66 \\
7\end{array}$ & 9.408 & 1.718 & -20.180 & -13.154 & 9.703 & 29 & .000 \\
\hline
\end{tabular}

Dari hasil perhitungan tersebut, nilai rata-rata hasil pretest adalah 59,67 dan rata-rata posttest adalah 76,33. Dalam ketentuan uji t-test adalah apabila sig. (2-tailed) $<$ 0,005 maka Ho ditolak dan Ha diterima.

Melalui uji Paired Sample T-test didapatkan nilai sig(2-tailed) 0,000<0,005, Ho ditolak dan Ha diterima. Sehingga dapat disimpulkan bahwa terdapat perbedaan antara nilai tes sebelum dan sesudah penerapan model Cooperative Learning tipe CIRC yang artinya terdapat pengaruh signifikan penerapan model Cooperative Learning tipe CIRC dalam maharoh qiro'ah siswa MTs Madinatunnajah kota Cirebon.

b. Uji Cohen's Effect Size

Penghitungan Cohen's Effect Size dilakukan untuk mengetahui seberapa besar pengaruh penerapan model Cooperative Learning tipe CIRC dalam keterampilan membaca dalam materi المهنة siswa kelas VIII MTs Madinatunnajah kota Cirebon. Berikut adalah rumus cohen's effect size one group beserta penghitungannya.

$$
\begin{gathered}
\mathrm{d}=\frac{\bar{x}_{1}-\bar{x}_{2}}{S} \\
\mathrm{~d}=\frac{76,33-59,67}{9,0408}=1,77
\end{gathered}
$$

Hasil perhitungan effect size 1,77 dengan sampel tiga puluh siswa menunjukkan bahwa pengaruh penerapan model Cooperative Learning tipe CIRC dalam keterampilan membaca dalam materi المهنة siswa kelas VIII MTs Madinatunnajah kota Cirebon kontribusi pengaruhnya $>1,00$ dan tergolong kuat atau tinggi.

\section{Kesimpulan}


Berdasarkan hasil penelitian yang dilakukan, maka dapat ditarik kesimpulan sebagai berikut: (1) kemampuan siswa dalam keterampilan membaca materi "siswa kelas VIII MTs Madinatunnajah Kota Cirebon sebelum penerapan model Cooperative Learning tipe CIRC, rata-rata pretest adalah 59,70, dengan kategori minimum 30 dan kategori maximum 95, (2) kemampuan siswa dalam keterampilan membaca materi "المهنة siswa kelas VIII MTs Madinatunnajah Kota Cirebon sebelum penerapan model Cooperative Learning tipe CIRC, rata-rata pretest adalah76,30, dengan kategori minimum 55 dan kategori maximum 100, dan (3) Adapun pengaruh penerapan Cooperative Learning tipe CIRC dalam keterampilan membaca dalam materi siswa kelas VIII MTs Madinatunnajah kota Cirebon menunjukkan adanya pengaruh signifikan, yakni hasil penghitungan melalui uji paired simple test Nilai sig(2-tailed) adalah 0,000<0,005, dan hasil perhitungan Cohens effect size adalah 1,77 dengan sampel tiga puluh siswa yang berarti model Cooperative Learning tipe CIRC pada kontribusinya dianggap kuat atau tinggi. Dengan demikian, Ha diterima dan HO ditolak.

\section{Daftar Pustaka}

Agasasmita, 2019. Peningkatan Kemampuan Membaca Teks Eksposisi Melalui Metode CIRC Siswa MTs. Artikel Penelitian. Universitas Tanjung Pura. Pontianak.

Delviani, Delia dkk, 2016. Penerapan Model Cooperative Integrated Reading and Composition (CIRC) Berbantuan Media Puzzle Kalimat untuk Meningkatkan Kemampuan Membaca Anak dalam Menentukan Pikiran Pokok. Jurnal Pena Ilmiah, vol. 1 (1).

Farboy, 2008. Penerapan Metode CIRC untuk Meningkatkan Kemampuan Menemukan Gagasan Utama Sebuah Teks Pada Siswa Kelas VII di SMP Negri 3 Batu Tahun Ajaran 2008/2009. Jurnal Artikulasi. Vol.7 (1).

Ni Nyoman Padmadewi, 2017. Pengantar Microteaching. Depok: Rajawali Press.

Nengsih, dkk. 2008. Penerapan Metode CIRC Terhadap menulis teks Ceramah pada Siswa SMA. Jurnal Pendidikan Bahasa dan Sastra Indonesia. Vol.2.

Oktafiani, 2018. Efektifitas Model Pembelajaran CIRC untuk Meningkatkan Kemampuan Membaca Pemahaman Anak Disleksi. UNES Journal of Education Science. Vol. 2 (2).

Suarni, 2016. Model Pembelajaran Koperatif dan Implikasinya pada Pemahaman Belajar Sains di SD/ MI (Studi PTK di Kelas III MIN 3 WatesLiwa Lampung Barat). Jurnal Pendidikan dan Pembelajaran Dasar. Vol.3 (2), hlm. 6 
Sugiyono, 2013. Metodologi Penelitian Kuantitatif dan R\&D.Hlm. Bandung: Alfabeta.

Slavin, 2010. Cooperative Learning Teori, Riset dan Praktik. Bandung: Nusa Media.

Thama, 2014. Kemampuan Membaca Pemahaman Siswa Kelas VII SMP Negeri 1 Kerkap Berdasarkan Taksonomi Barret. Skripsi Pendidikan Bahasa dan Sastra Indonesia. Universitas Bengkulu. Bengkulu.

$$
\text { عاطي، } 1996 \text { ـ طريقة تلدريس اللغة العربية والتربية الدينية مكتبة. ـ إبراهيم محمد. 1996. طريقة تلديس اللغة }
$$$$
\text { مرزوقي، توفيق. 2009. نموذج التعليم التعاوني وفعاليتها في تنمية مهارة الكتابة. رسالة كلية الدراسة العليا قسم }
$$$$
\text { تعليم اللغة العربية. جامعة مولانا مالك إبراهيم الإسلامية الحكومية: مالانج. }
$$ 